\title{
SURVEY OF LAVA TUBFS IN THE FORMER PUNA FOREST RESERVE AND ON ADJACENT STATE OF HAWAII LANDS
}

\author{
H. McEldowney \\ A.B.D, Prehistory, Australian National University \\ Staff Archaeologist, State Historic Preservation Division \\ F. D. Stone \\ Masters of Science, Entomology, Cornell University \\ PhD., Geography, University of Hawaii \\ Instructor in Science, Hawaii Community College \\ Prepared for: \\ State Historic Preservation Division \\ Division of Water Resource Management \\ Department of Land and Natural Resource, State of Hawaii
}




\section{DISCLAIMER}

This report was prepared as an account of work sponsored by an agency of the United States Government. Neither the United States Government nor any agency Thereof, nor any of their employees, makes any warranty, express or implied, or assumes any legal liability or responsibility for the accuracy, completeness, or usefulness of any information, apparatus, product, or process disclosed, or represents that its use would not infringe privately owned rights. Reference herein to any specific commercial product, process, or service by trade name, trademark, manufacturer, or otherwise does not necessarily constitute or imply its endorsement, recommendation, or favoring by the United States Government or any agency thereof. The views and opinions of authors expressed herein do not necessarily state or reflect those of the United States Government or any agency thereof. 


\section{DISCLAIMER}

Portions of this document may be illegible in electronic image products. Images are produced from the best available original document. 
This study was initiated after members of the Puna community brought to the attention of the Historic Preservation Office that major lava tube systems extended from the Pahoa area into at least portions of the former Puna Forest Reserve (TMK: 3-1-2-10: 2 and 3). They were concerned that planned geothermal exploration and development could damage these lava tubes which they said contained extensive evidence of past Hawaiian use including fortifications, shrines, platforms and burials. Geothermal development is currently being planned by Campbell Estate and True Geothermal Energy Company in the southern portion of the former Reserve which has been designated by the State of Hawaii as one of the three Geothermal Sub-Zones in Puna.

To demonstrate these claims, two staff members of the Historic Sites Section were shown examples in a lava tube makai of the Campbell Estate boundary. After reviewing the archaeological and historical reports commissioned for geothermal exploration, it was agreed that if these lava tubes did extend inland and continued to contain archaeological sites or burials then the potential of significant sub-surface sites had not been adequately addressed in the Historic Sites Section review process. Most reports acknowledged the possibility of lava tubes in the area and that they could contain burials, but no tube systems were ever identified or explored during any of the field surveys. These surveys primarily assessed the presence or absence of cultural properties that occur on the surface or as deposits within the soil layer (see discussion below).

With the assistance of the Division of Water Resource Management (DWRM), the Historic Sites Section agreed to conduct this survey because those community members who came forward requested that this information be handled by a neutral party. They asked that documentation occur in such a manner that it could be kept as confidential as possible while still providing enough information to protect any sites from damage.

The survey had three major aims. The first was to establish whether or not the lava tubes continued into the land now held by Campbell Estate or the Geothermal Sub-Zone. The second was to assess the extent to which any lava tube systems found contained archaeological remains or burials and, if so, to evaluate their general significance. The third was to define, if possible, any patterns in the distribution of the lava tube systems or the archaeological remains within them. Such patterns can allow general predictions to be made about which areas are most likely to have similar tube systems with significant archaeological sites. This is of particular importance in this region where large portions of the former Forest Reserve and the Geothermal Sub-Zone have not been inspected, and conducting extensive surveys is extremely difficult because of dense vegetation, hazardous conditions and poor ground visibility. One of the authors (Stone) has a background in Hawaiian lava tube biology, so we were able to include a preliminary survey of the invertebrate fauna found in these underground ecosystems.

Although only a small portion of the Campbell Estate land could be covered during this survey, it indicated that extensive lava tube systems do extend into the former Puna Forest 


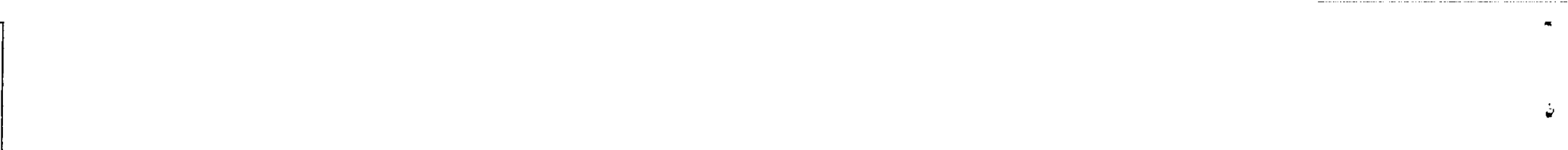


Natural Area Reserve. Because there is no single place name for the study area it will be called the Puna Forest Reserve or Campbell Estate land in the following report.

The topography and surface geology of the study area reflect the very active and recent eruptive history of Kilauea Volcano. The Middle East Rift Zone dissects the property and lava from it and the Summit Region of Kilauea have created a variable surface of differing flow types and ages. Much of the surface near the Rift has been fractured by fissures and numerous long faults or cracks. Approximately a fourth of the parcel lies on the steeply sloping south flank of the Rift and the remainder extends across the broader and more gently sloping north flank. According to Holcomb's map of Kilauea's surface geology and eruptive history (Holcomb 1980), lava flows grouped as historic (1840 to 1977) or as forming during the late 1700 's, dominate the middle rift zone itself and that part of the south flank which falls within the study area. Defining flow boundaries and age groupings on the north flank was more difficult because of dense vegetation cover, particularly in the up-slope areas. Roughly half are defined as being composed of flows dated between 350 and $500 \mathrm{BP}$ with the remainder estimated to be older than $1500 \mathrm{BP}$. The younger flows, grouped as the Ai-Laau series, are mainly comprised of long-duration, tube-fed pahoehoe flows which cover most of Kilauea's north flank and approximately $30 \%$ of the surface of Kilauea Volcano (Holcomb 1987:346). Kilauea has created some of the longest lava tubes in the world and many of these, including those described in this report, formed during this period. The highest single, topographic feature within the property, Puu Heiheiahulu, lies to the south of the rift and formed as a lava shield with a crater during the 1700's.

\section{Historical and Archaeological Work.}

Most historical and archaeological studies conducted for geothermal development in the Puna Forest Reserve repeatedly portray the area as a remote and inhospitable rain forest in which human use was periodic and sparsely distributed. Dominating these activities were the gathering of forest resources, including bird catching, the use of trails and temporary habitation associated with these activities. Burial, religion and limited agriculture were also given as possibilities although less frequently. Most researchers believed that tangible remnants of all these activities should be present but they expected them in low numbers and to be difficult to recognize, particularly when compared to those found in the more intensely used coastal areas or prime agricultural lands. The dominant activities were seen, at least in this region, as being less prone to produce stone, structural remains or substantial deposits of durable food remains, debris from tool manufacture or charcoal. The distribution of potential remains was not only predicted to be sparse but uneven. Greater concentrations were expected along trails, in areas where lava tubes could provide shelter or burial sites and in the seaward portions of the parcel where limited agriculture may have taken place. All studies emphasize the problems of dense vegetation which compound the difficulty of finding what is already hypothesized to be scant evidence. The vegetation 
'awapuhi (Zingiber zerumbet). Kukui was seen on two reconnaissance transects along the south flank of the Rift Zone at elevations of 1,500 and 1,440 ft (Haun, Rosendahl and Landrum 1985:6) and at a proposed well site on the northern flank at 1,480 ft above sea level (Lamoureux, Whistler and Imada 1990:5). Ki is more common, occurring in a scattered distribution on both the southern and northern flanks to a maximum elevation of $1600 \mathrm{ft}$ (Haun, Rosendahl and Landrum 1985:6,7; Bonk 1989c:11; 1990:7; Lamoureux, Whistler and Imada 1990:2). The two sightings of banana from the helicopter were both on the southem flank slightly below the 1,600 ft elevation (Haun, Rosendahl and Landrum 1985:Fig. 23). 'Awa was also seen at the 1,240 ft elevation (Bonk 1989c:11; True MidPacific 1985:Appendix A) and a few examples of 'awapuhi were noted during the survey of three proposed well pads and access roads (Bonk 1990:7; Lamoureux, Whistler and Imada 1990a:5; Lamoureux 1990b:9). These plants, particularly kukui, $k i$ and banana, are considered probable indicators of past use for two reasons: they were of great value and utilitarian importance to the Hawaiian culture and are unlikely to become established in rain forest communities without the aid of man either through propagation, clearing or initial tending.

In regard to lava tubes, a major oversight of these studies was the omission of Yent's survey (1983) of a "Pahoa Cave" (called the Middle Tube System here). Although the report shows the location of a single entrance on State land to the east of Campbell Estate property, the distances and bearings given in the report indicate that Yent explored at least 2,000 $\mathrm{ft}$ into the Forest Reserve and found defensive structures, burials, midden deposits and terracing within this stretch. Despite this omission, three overviews did consider the possibility of lava tubes with archaeological remains. The Research Design calls for surveys to pay special attention to pahoehoe flows where lava tubes could be present and could contain remnants of campsites and burials. The assessment of archaeological potential for all three Geothermal Sub-Zones simply stresses that lava tubes with remains rank as one of the major site types of Puna (Cultural Surveys of Hawaii 1989). Holmes felt that it "would not be unreasonable" to "conjecture" that there were caves in the Forest Reserve (Holmes 1985:6). Their significance, however, would be "minimal" because they would be "occasional shelter or possibly but not likely burial (because of distance from regular habitation)" (Ibid.). Our survey demonstrates that, to identify lava tubes within a study area, it may be necessary to begin the search, either in the literature or on the ground, from neighboring parcels.

\section{Native Invertebrates and Lava Tube Ecosystems}

Hawaiian native invertebrates as a whole have won recognition in the world scientific community as being an integral part of Hawaii's unique "evolutionary experiment." An important dimension of studying these evolutionary processes in Hawaii has been to contrast these cave-dwelling species with their surface-dwelling relatives. There are few other areas in the world where it is possible to find related yet distinct taxa existing both above and 

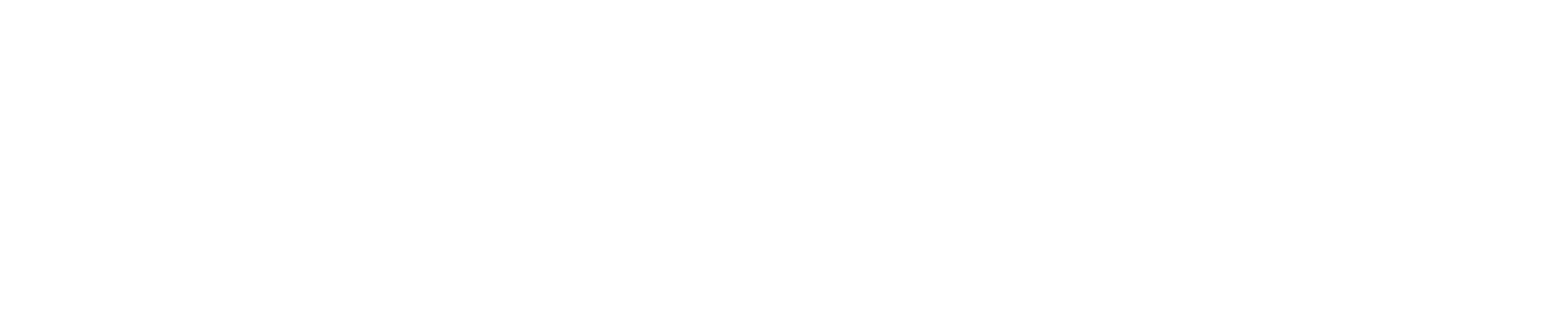
could extend into the Geothermal Sub-Zone or near the proposed well sites. This remained a strong possibility because the up-slope extent of all three tubes and their eruptive sources have never been identified because dense vegetation obscures evidence of tube directions or flow boundaries throughout much of the property.

In the following report, these three tube systems, or segments of them, will be referred to as the Southern, Middle and Northern Tube systems. A total of 11 days was spent in the field searching for tube entrances above ground and mapping those which could be followed. In addition, a three-hour helicopter survey helped locate entrances on aerial photographs and probable access routes to them. In all, 42 tube entrances were visited, about nine miles of lava tube were traversed, and approximately 6.6 of these were mapped. Another 12 to 13 miles were covered above ground by foot in attempts to find additional entrances. This effort still represents coverage of less than $1 / 4$ of the area which could have lava tubes or tube segments on Campbell Estate land.

The lava tubes were mapped by the pace and compass survey method with corrections in alignment and distance being made where tube entrances could be identified and plotted on aerial photographs. This method was chosen primarily for its speed. Although relatively less accurate than other methods, it was the most efficient for documenting the course of tube systems given the limited time available and rigorous working conditions which included climbing numerous collapse piles and crawling through tight passages. With these limitations in mind, this study and the maps produced should be considered preliminary and are by no means complete or exhaustive.

\section{SOUTHERN TUBE SYSTEM}

Instead of a continuous tube system, only four tube segments could be found within a corridor that approximates the hypothesized Southern Tube. Three days were spent searching 3.2 miles of the hypothesized tube course from an elevation of 700 to $1200 \mathrm{ft}$. About 0.7 miles of this area lies within the Geothermal Sub-Zone where dense vegetation made looking for additional entrances inland unfeasible. It is possible that additional segments occur further inland in the subzone, but rigorous surface reconnaissance will be necessary to locate them. In all, an estimated 10 to 12 miles were covered above ground in the effort to locate tube openings.

Of the four segments, three were primarily used as burial tubes and each was located on State Land adjacent to the sub-zone. No evidence suggests that these burial tubes served any other function and the two larger segments, both described below in more detail, should be considered major burial caves as they contain a combined total of at least 100 individuals. The third segment (Site 50-10-55-14,903), located between the 930 and $950 \mathrm{ft}$ contours, was little more than a narrow space surrounding the base of a collapse pile that filled most of the entrance. The badly disturbed bones of a single individual were mixed 

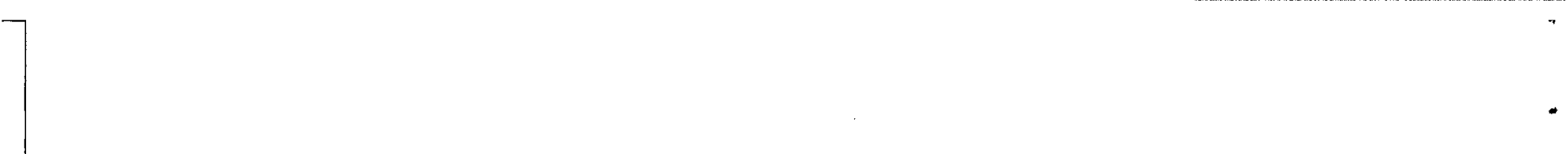
Fig. 1 Southern Tube System - Lower Segment

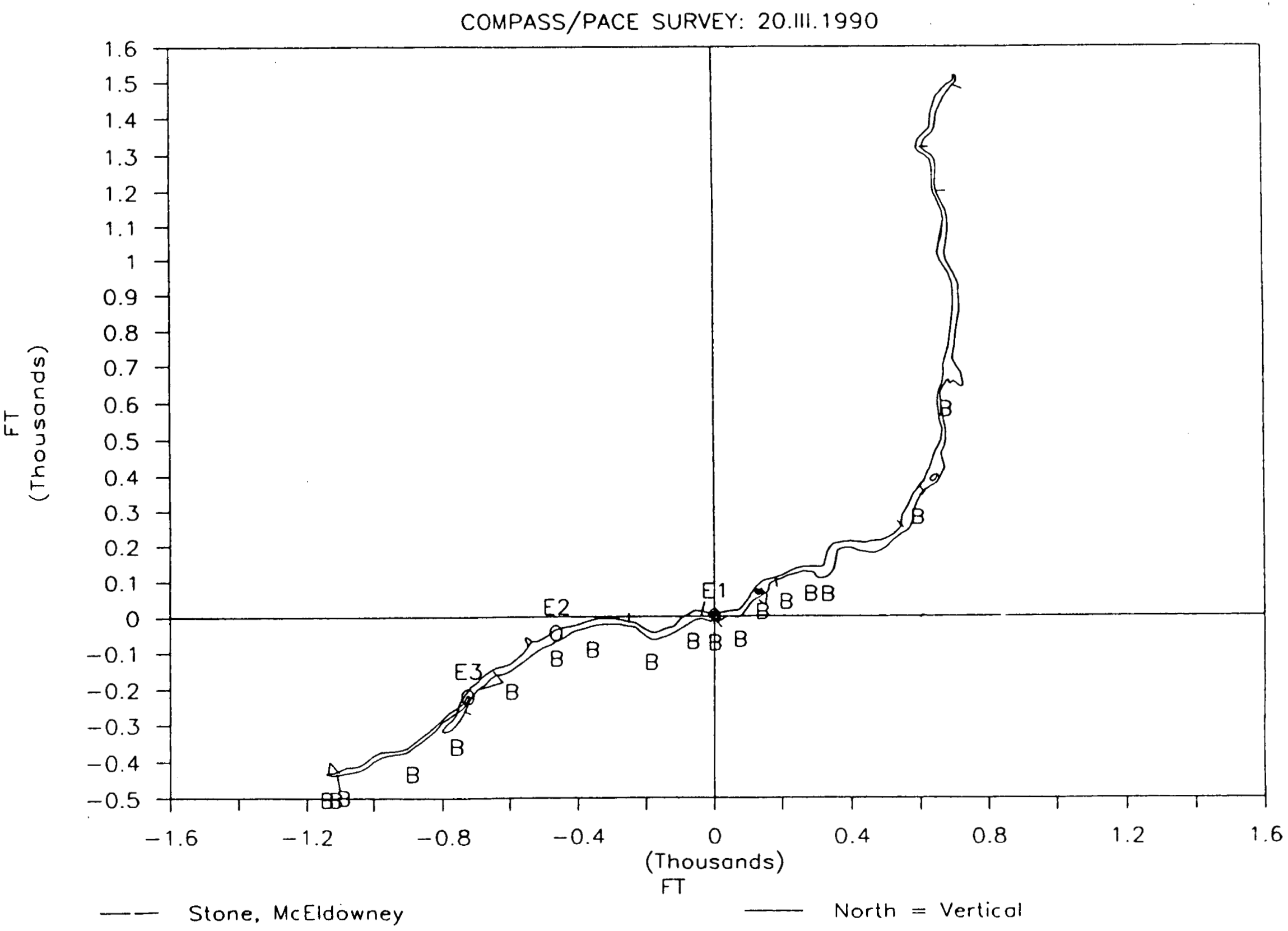

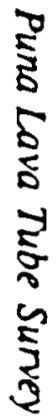


the passage above. In the elevated passage, remains of 5 to 10 individuals cover the floor and are tucked in crevices along the tube walls. The remains are mixed with charcoal or decayed organics throughout and one red glass bead and some bottle glass were also present, suggesting that at least some of the burials date to the historic period. A strong breeze from a nearby entrance can be felt through cracks in the ceiling above the passage suggesting that an opening may have been artificially sealed with break-down rubble and roof fall slabs.

St. U12 to U11 - Up-slope from the St. U11, badly deteriorated human bone and charcoal are dispersed for a $20 \mathrm{ft}$ stretch of the tube floor. The occasional scatter of charcoal and wood splinters continues beyond the bone scatter.

St. U10 to U9 - With the exception of horse bones and old bottles which were probably used as kerosene lamps, nothing was found between these stations and an upper level passage of the tube which truncates after $150 \mathrm{ft}$.

St. U9 (Entrance 3, Fig. 2a) to U8 - The double entrance at Station 9 is separated by a natural bridge. What appears to be an artificial or modified gap ( $2 \mathrm{~m}$ wide, 5 $m$ long) crosses the down-slope end of the collapse pile under the lower entrance. The tube splits into an upper and lower passage below this entrance. The lower area has the appearance of having been roughly paved with a layer of flat, roof fall slabs.

St. U7 to U8 - Only one human bone lay on the tube floor down-slope of Station 8.

St. U7 to U6 (Entrance 2, Fig. 2a) - Two elevated shelves halfway between the stations contain burials as well as sizable amounts of organic matter, wood fragments and, next to at least one burial, a medicine jar and buttons. Large rocks appear to have been intentionally scattered on the floor, one being placed as a stepping stone to the ledge.

St. U5 to U4 - Human bone was found on shelves along the Hilo and $\mathrm{Ka}$ 'u side of the tube as well as scattered across the floor. The shelf ( 1 by $10 \mathrm{~m}, 1 \mathrm{~m} \mathrm{high}$ ) on the $\mathrm{Ka}^{\prime} \mathrm{u}$ side probably holds several individuals whose bones are dispersed for several meters along the shelf and mixed with historic artifacts (glass, Chinese teacup, bottles, and long wood fragments with nails). On the Hilo side, human bone on the shelf ( 1 by $4 \mathrm{~m}$ ) and floor are mixed or covered with substantial amounts of decaying wood fragments that obscure parts of the burial.

St. U4 - A single, badly deteriorated burial lies on a shelf ( $3 \times 7 \mathrm{~m}, .75 \mathrm{~m}$ high) about $2 \mathrm{~m}$ up-slope from the station. Several small pieces of plastic are mixed with the burial. 
Fig. 2a Detail of Southern Tube System - Lower Segment (Map 1)

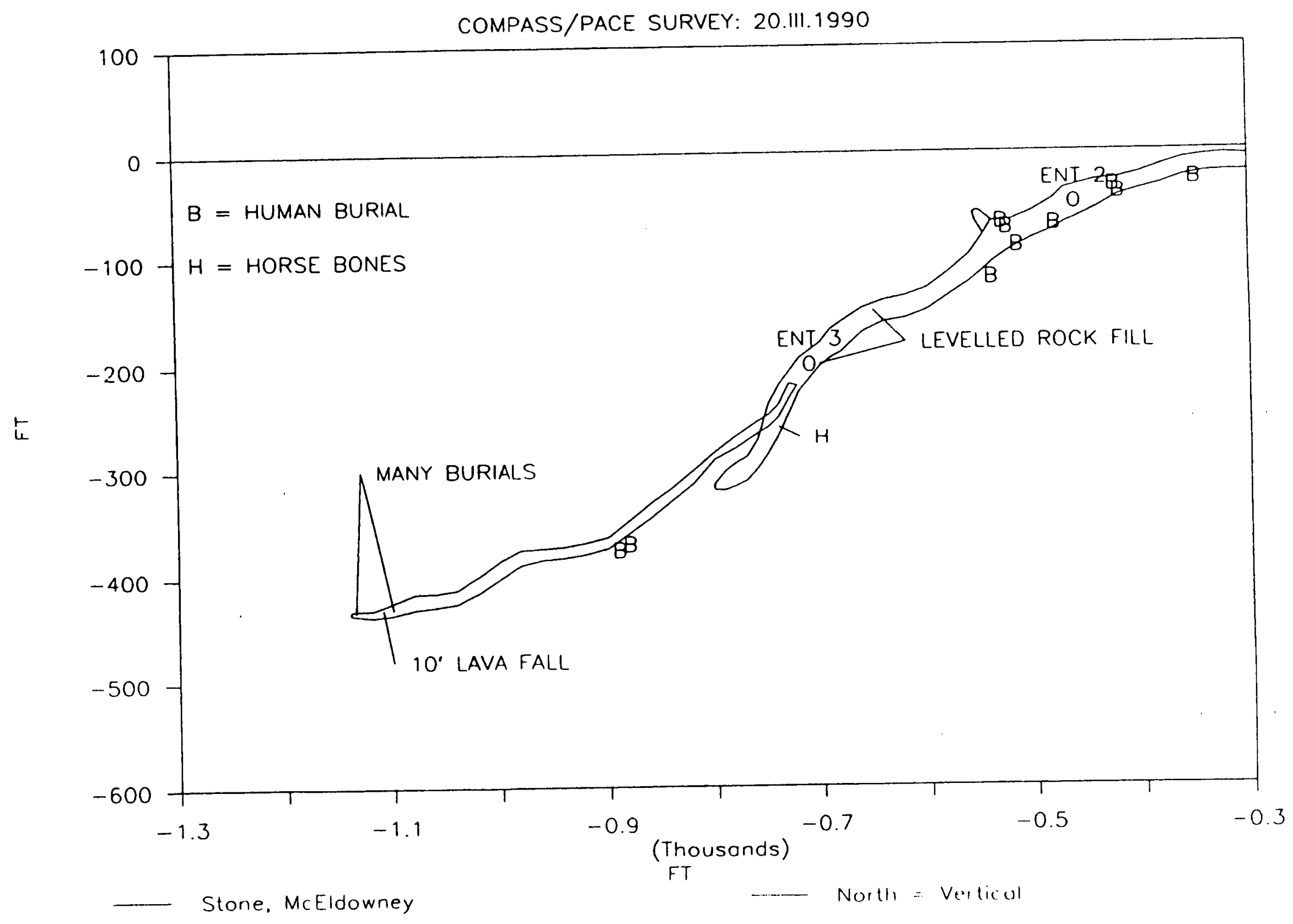



Fig. 2c Detail of Southern Tube System - Lower Segment (Map 3)

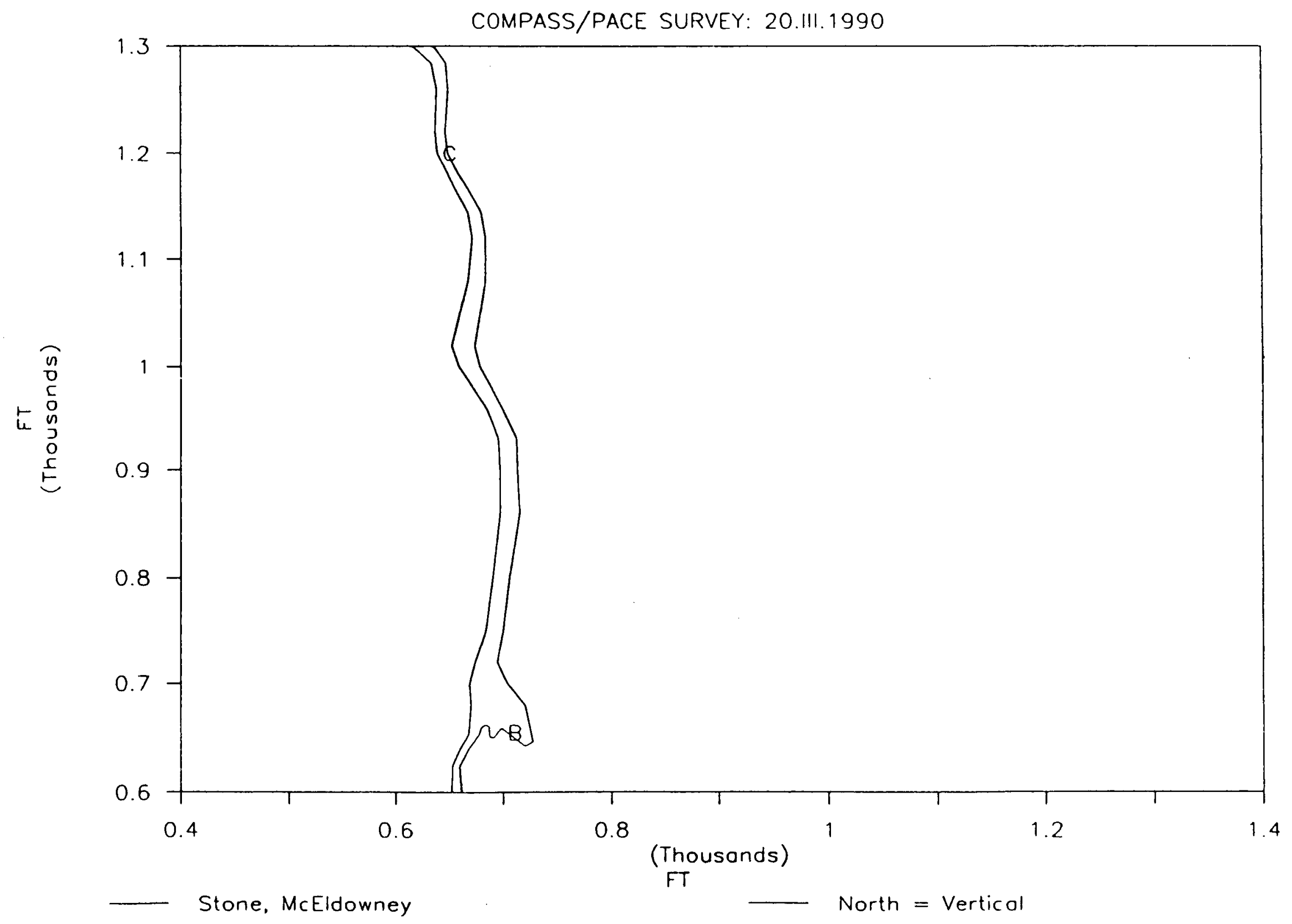

2
5
5
5
5
5
5
0
5
5
3 
St. D6 - On the Ka'u side of the station, remains of a single individual lie on a broad shelf $(1.5 \mathrm{~m}$ wide). The badly fragmented skull indicates that it is the remains of a single individual. An old bottle was also placed on the shelf but it is not clear if it was associated with the burial or if it was left by someone passing through.

St. D6 to D10 - The only sign of human use in this stretch of tube was a single bottle on a shelf and scattered charcoal fragments along the tube floor. Burials were absent despite an ample number of shelves.

St. D11 - About $4 \mathrm{~m}$ from the station, an extended burial lies on the floor of the tube parallel and adjacent to the tube wall. The long piece of wood remaining with the burial could have been a litter stick used to carry the body. The skull, although badly collapsed, was still evident.

St. D12 to D13 In this stretch, only a few pieces of charcoal were evident on the floor and collapse piles.

St. D14 - A scatter of very small, non-human bones was found about $20 \mathrm{ft}$ downslope from St. D14 on the Ka'u side of the tube. It was difficult to tell if it should be considered midden or the remnants of a natural death.

St. D15 to D16 - Ten meters up a side passage, an extended or flexed burial of a single individual is either covered or mixed with large amounts of charcoal or decaying organics. Many shelf formations are available in this section of the tube but none were used for burial.

St. D17 to D27 - The remainder of the tube contained only scattered fragments of charcoal indicating that this down-slope segment was at least explored. The upslope portion of this segment is broad but becomes gradually more narrow as the tube ends in a low crawl and a lava seal. A large number of lava drip spires formed in this section as the flow of lava slowed and cooled at this impasse.

\section{Upper Segment of the Southern Tube (50-10-55-14,902)}

Located at an elevation of approximately $930 \mathrm{ft}$, this tube segment is entered through a small opening in the side of an elongated collapse which resembles an open trench. It could only be followed down-slope for a distance of $250 \mathrm{ft}$ and averages 20 to $30 \mathrm{ft}$ in width and 8 to $10 \mathrm{ft}$ in height. An estimated 30 to 35 individuals were buried by being placed on the tube floor, on low shelves, within shallow holes in break-down piles or, in one case, on an intentionally leveled rubble pile or platform. As was the case in the lower segment, estimating the number of burials was difficult because the bones are badly deteriorated or 
A total of five days was spent exploring and mapping this one tube. On the first day, the survey began near the highway to verify that the tube segment previously mapped by Stone extended to the Campbell Estate boundary and that it linked with that mapped and described by Yent (1983). Once this was established, four days were spent exploring and mapping the tube in successive increments inland through the Campbell property and into the Geothermal Sub-Zone. It took approximately 16 hours to reach and retum from entrance 32 and to map the last section surveyed.

The following descriptions of the Middle Tube and the archaeological remains encountered address only the upper 5.1 miles of the tube or that which runs between entrances U2O and U32 (Figs. 6a-6c, 7a-7e). Of this stretch, 4.2 miles essentially cut through the center of the Campbell Estate parcel in a northeast to southwest direction. Each entrance is numbered in ascending order from the main Pahoa highway and carries the prefix $U$ to designate that it lies up-slope of the highway. Again, because the tube meanders substantially, magnetic orientation is not used to designate which side of the tube is being discussed. Instead, anything noted as being on the Hilo side lies on the right hand side of the tube as one faces up-slope and that on the left hand side is noted as being on the Ka'u side.

An additional lava tube was entered near entrance U20 of the Middle Tube. Only a few hundred feet was explored and no evidence of human use was found. This tube should be fully explored in the future, particularly if there are any planned development activities to the north of the Middle Tube. ${ }^{1}$

Despite occasional sections where the tube narrows to crawl ways or is constricted by break-down piles, the average width and height of the tube chamber remained relatively similar throughout the length mapped. Between entrances U20 and U27 (3.5 miles), the width of the tube averages 15 to $16 \mathrm{ft}$ and, above $\mathrm{U} 27$ (1.6 miles), it averages $20 \mathrm{ft}$. The average heights vary from 11 to $13 \mathrm{ft}$ throughout the 5.1 mile stretch. Some of the larger chambers mapped reach maximum widths of 35 to $40 \mathrm{ft}$ and have heights of 20 to $25 \mathrm{ft}$.

Not only is this tube notable for its size, but two long sections run continuously without any openings or entrances to the surface, one being 1.4 miles long (U20 to U21) and the other

\footnotetext{
'On July 20,1991, we mapped three tube segments from this entrance; two that branch from the initial entrance and eventually rejoin and a third which leaves and rejoins the northern segment. These segments continued 1,370 ft up-slope until roof collapse and lava seals blocked passage and no additional entrances were readily found above ground. Chamber width averages $20 \mathrm{ft}$ while heights range between 6 and $12 \mathrm{ft}$. If unexplored segments continue up-slope on the same orientation, they could intersect the Middle Lava Tube at the first major bend up-slope from entrance U20. Of the four entrances visited, three contained evidence of human use that essentially conforms with that found at entrances of the Middle and Northern Tube. Breakdown piles at or near the entrances were shaped into several small platforms, leveled areas or, in one instance, short wall segments bordering modified areas. These and deposits of charcoal, kukui and 'opihi suggest intermittent use by those working in the area or passing through. No attempts at fortification were noted nor were any burials seen although some could be well hidden.
} 


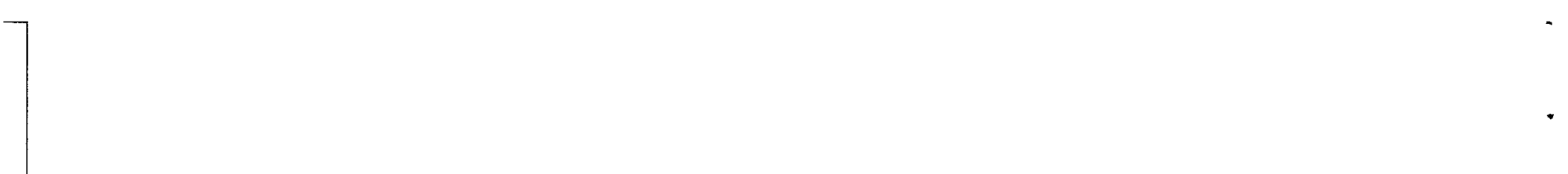


Fig. 3 Middle Lava Tube System and Known Tube Entrances to the Northern Tube System

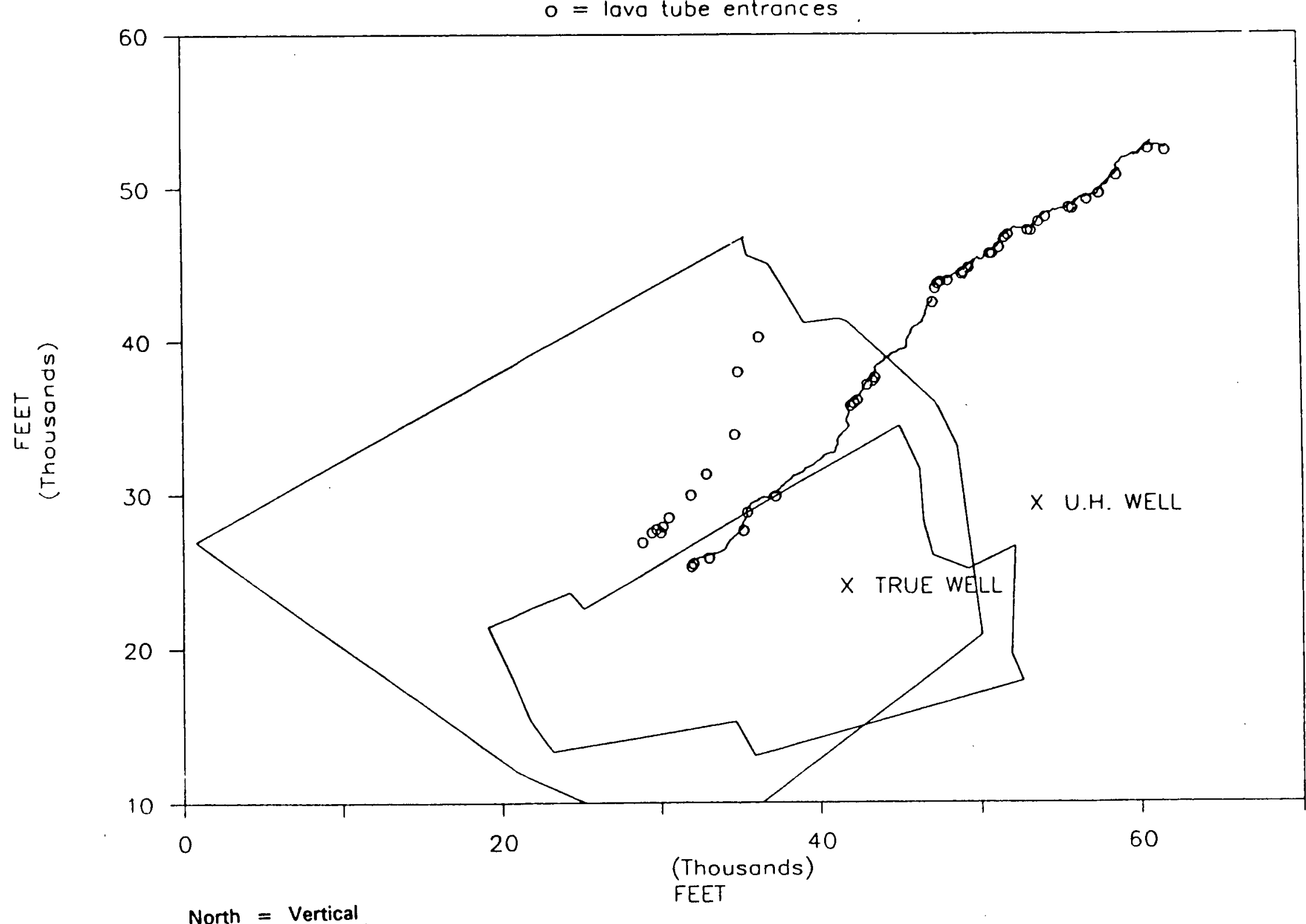

0
5
5
5
5
5
5
0
5
5
3 


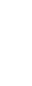


features. Although they seem to have no apparent function and their size and shape varied considerably, they appeared to be out of place and could not be readily attributed to a nearby source. Overall, the general lack of artifacts throughout the tube, even when Yent visited it in 1984, may indicate that the tube has been looted of most artifacts. Signs of modern visitors were apparent as far inland as just beyond entrance $\mathrm{U} 26$.

Although burials are present in the Middle Tube, this use should probably be considered secondary to its other functions. By combining our observations with those of Yent, we can say that there are at least a total of 15 individuals buried at seven different locations from the area around $\mathrm{U} 20$ to that of $\mathrm{U} 32$. This does not include the one instance in which fragments of human bone were found on the tube floor. Because of time constraints, we were unable to search all the ledges or side passages for potential burials during our survey and it is therefore possible that the actual number of burials is substantially greater than that indicated by this total. This is illustrated by the fact that at least three of the burials recorded by Yent may not have been found during our survey because of the speed with which we had to map the tube and describe the archaeological features found in order to reach the inland portions of the tube. Despite these limitations, the number of burials probably does not approach that recorded in either of the two segments of the Southern Tube System where burial was apparently the exclusive use of the tube segments, and the chambers were probably used repeatedly for this purpose.

Within these 15 examples, extended, flexed and bundle burial positions are all represented. Burials were also placed in a variety of locations including elevated ledges, recessed corners, side passages, the base of collapse piles and the middle of the tube floor. With the exception of those found up-slope of entrance U20 and U23, most are located in areas that are spatially discrete or removed from areas where other major activities took place. In two cases, both reported by Yent, roof fall debris was used either to cover the burial or surround it. No grave goods were found with any of the burials which again may indicate that the lava tube may have been looted. The lack of any historically manufactured items, particularly small glass beads, suggest that the burials are more likely to be prehistoric than historic period burials. Most burials appeared to be those of adults although we caution that neither author has the background to make definite age determinations.

Detailed Archaeological Descriptions of the Middle Tube between Entrances U20 and U32

U20 (900 ft el., Fig. 4a, 5a) - Of all the tube sections described below, that which extends from this entrance contains the greatest amount and diversity of evidence for past Hawaiian use. The following description essentially summarizes that given by Yent (1983) with some of our own observations and interpretations added. 
Fig. 4a Middle Lava Tube with Numbered Entrances - Up-slope End of State Land

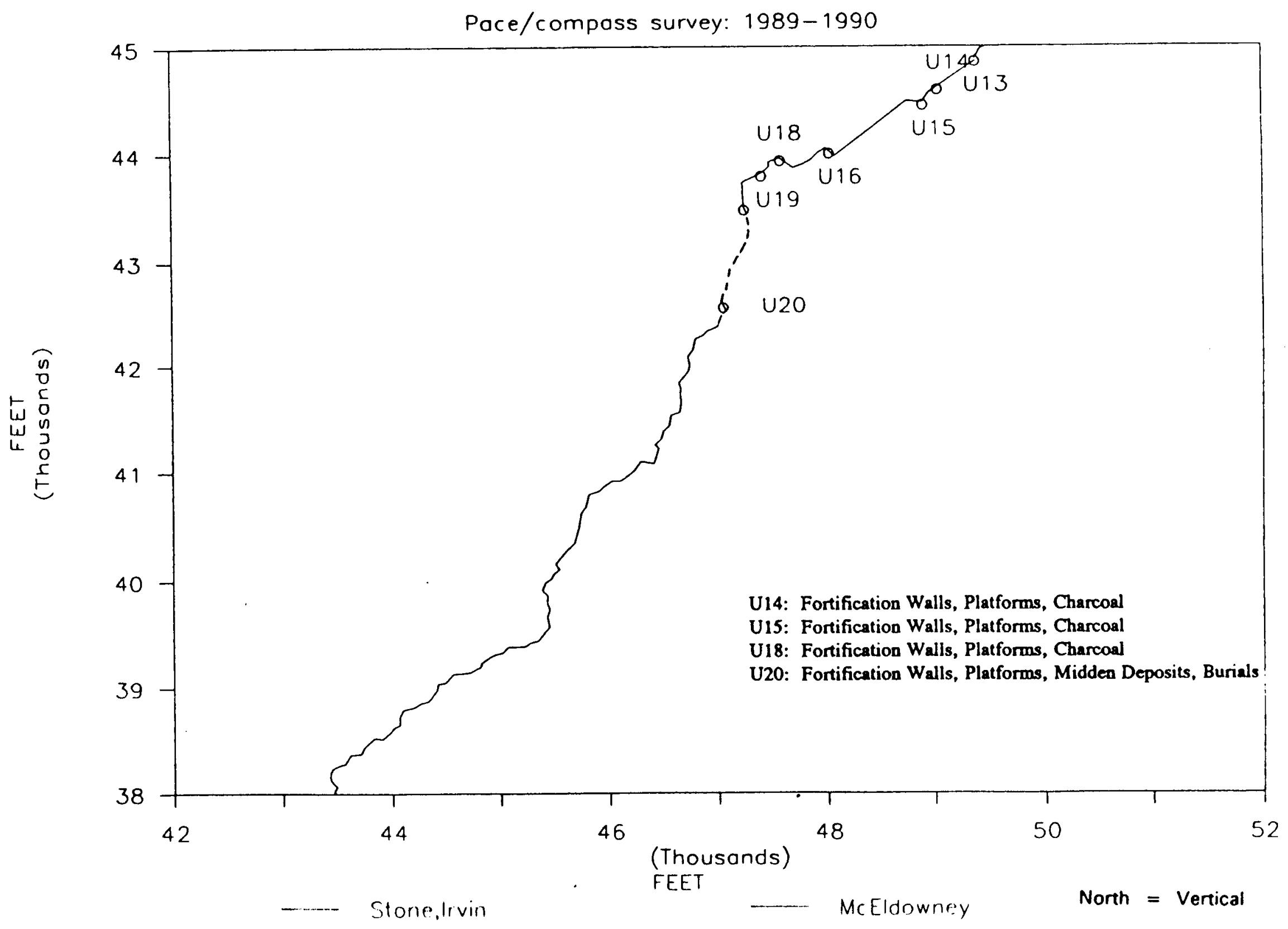



Fig. 4c Middle Lava Tube with Numbered Entrances - Campbell Estate Land and Geothermal Sub-Zone

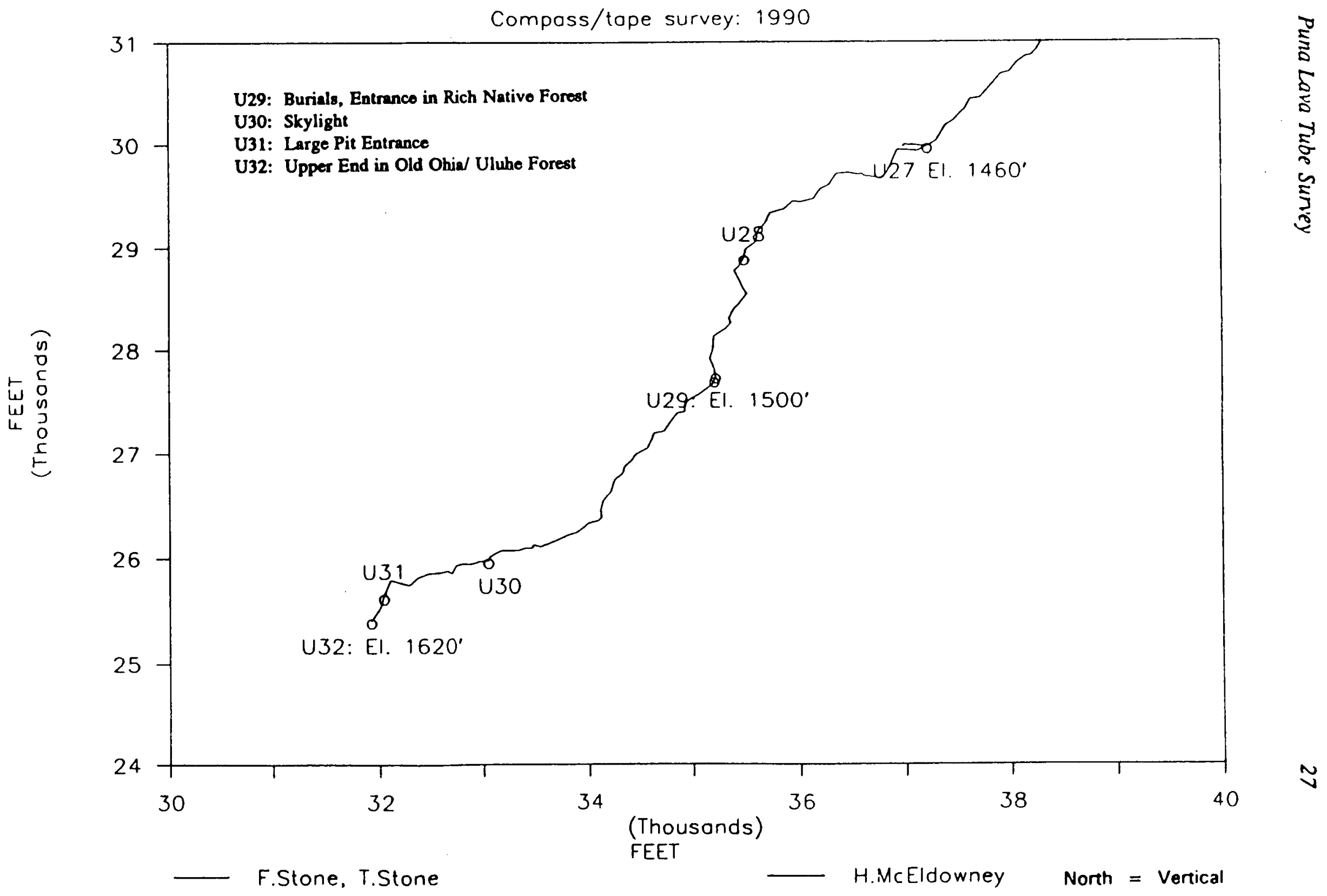


Fig. 5b Middle Lava Tube with Numbered Entrances - Distribution of Natural Features, Collapse Piles, Archaeological Features, Cave Invertebrate Species and Tree Root Formations

Composs/poce survey: Mar. 1990

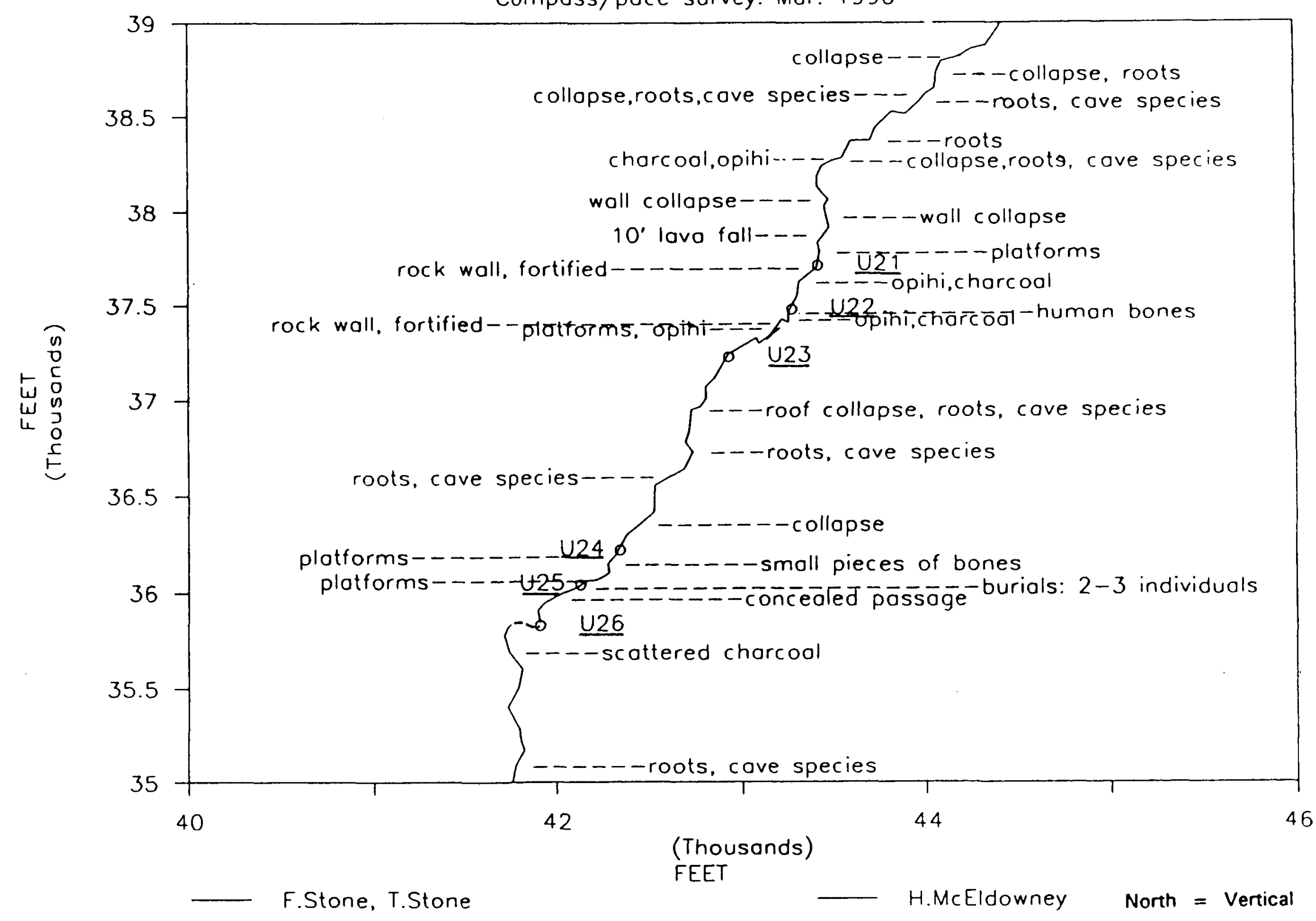




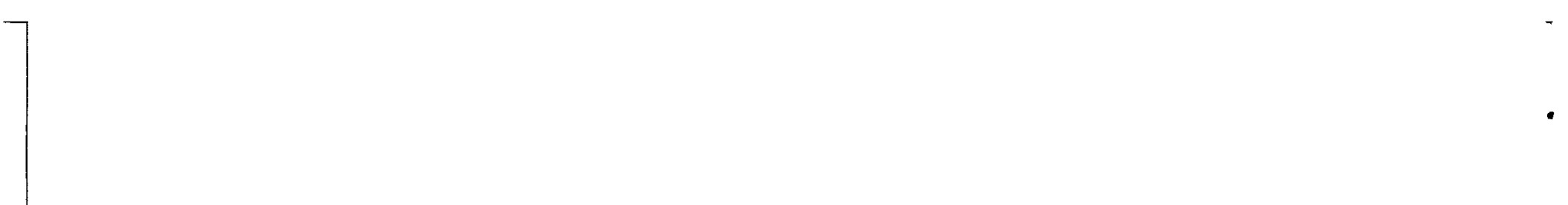

7

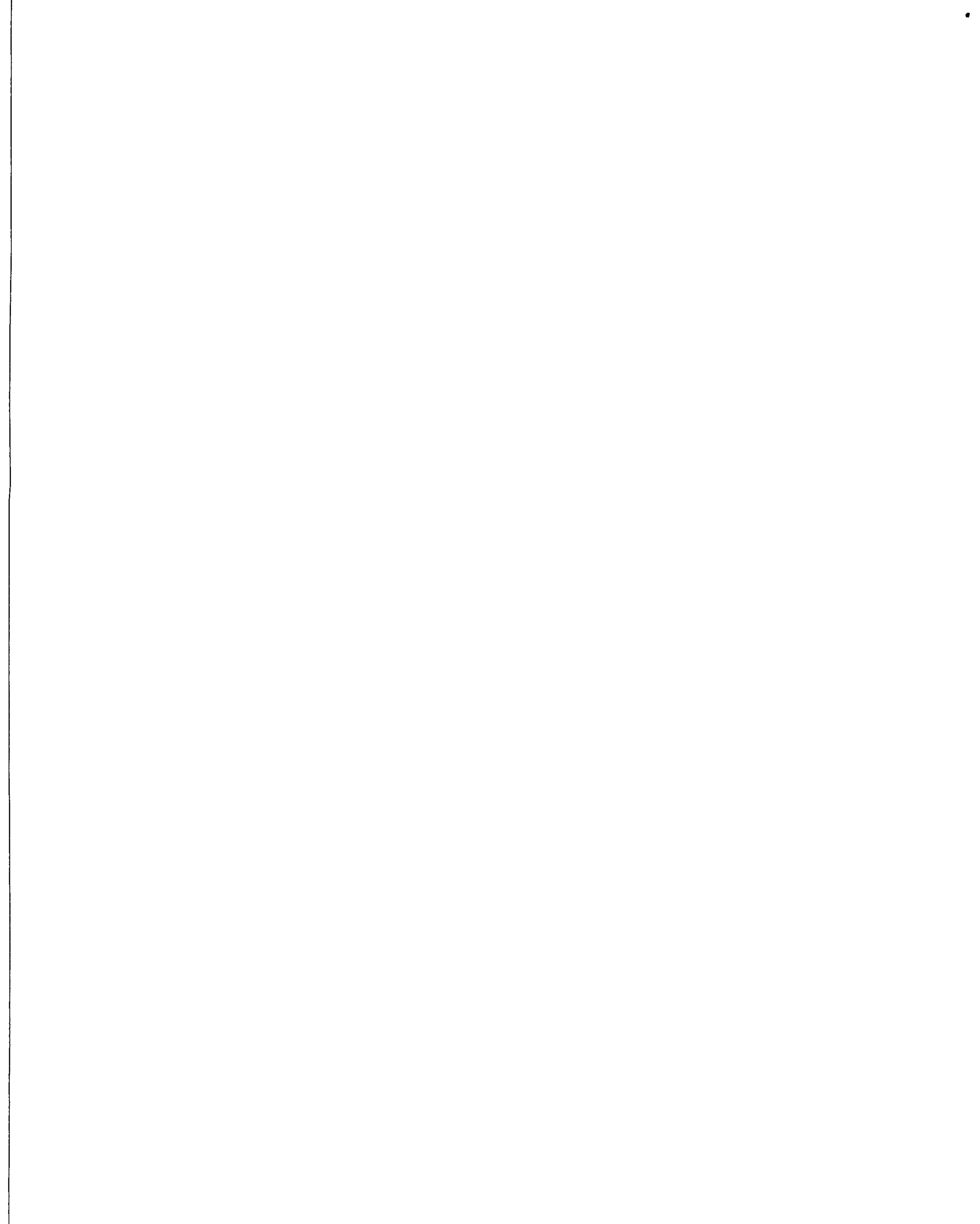


Fig. 5d Middle Lava Tube with Numbered Entrances - Distribution of Natural Features, Collapse Piles, Archaeological Features, Cave Invertebrate Species and Tree Root Formations

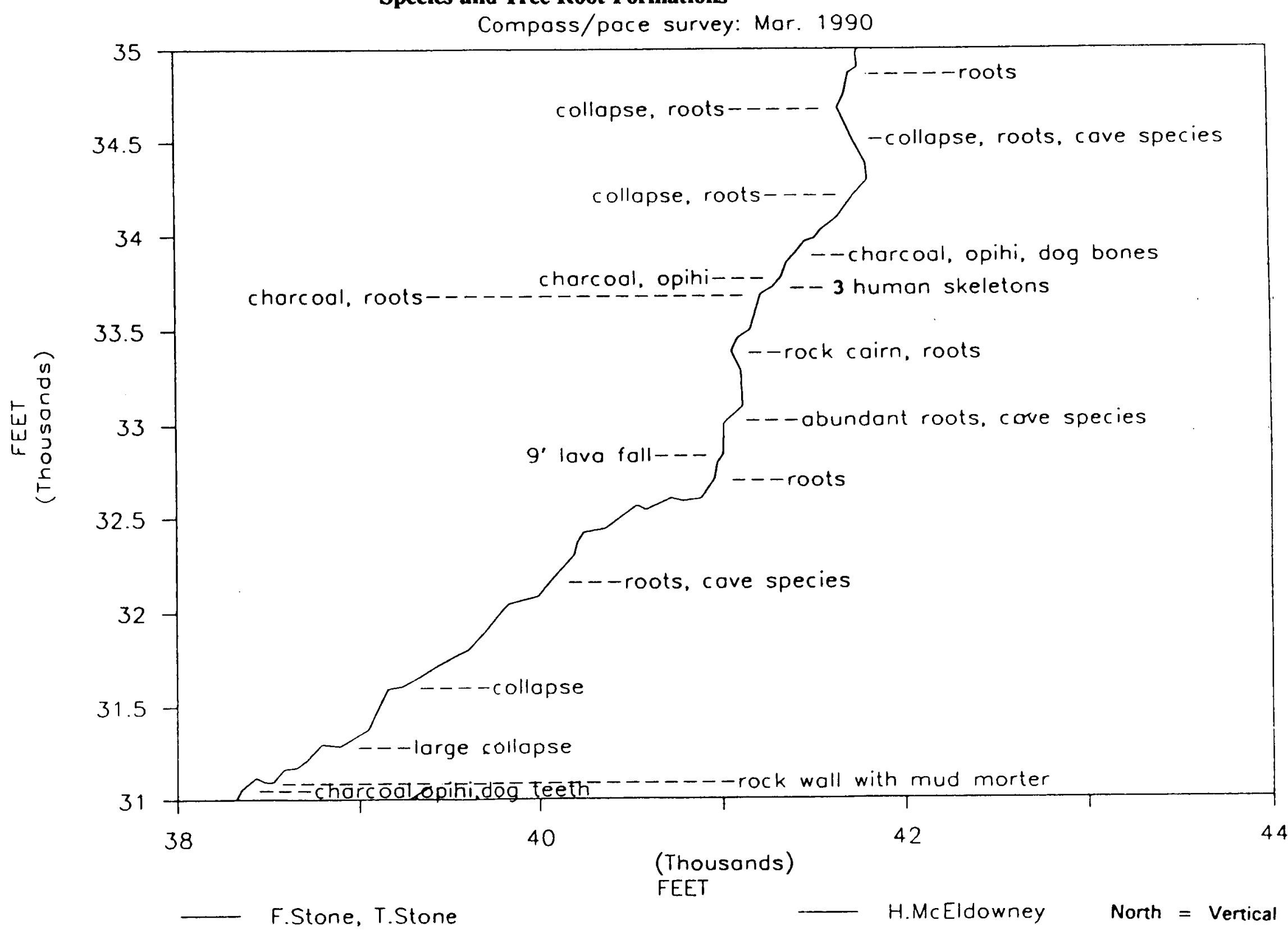


$$
\text { . }
$$

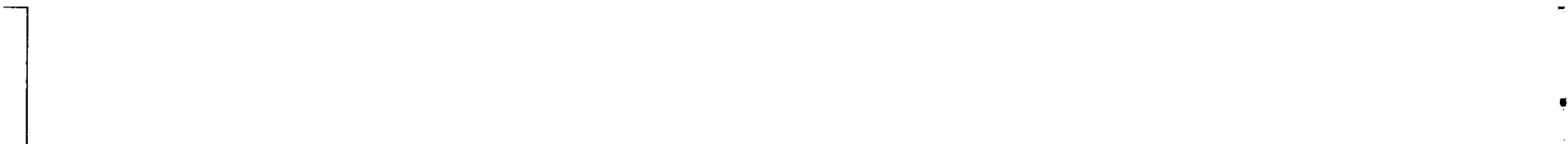


concealed by stone on one of the natural, elevated shelves that run along the walls of the tube.

For approximately $100 \mathrm{ft}$ above the wall, substantial amounts of break-down debris have been modified and rearranged to form broad level areas and two distinct platforms. Midden, charcoal, wood, unidentified organics and several rock-lined fire pits occur throughout the reworked area. The well-formed platforms are basically rectangular $(2$ by $3.5 \mathrm{~m}$ and $2 \times 3 \mathrm{~m}$ ) and $50 \mathrm{~cm}$. high. Their function is not clear and it is possible that they were built either for burials or as resting surfaces. Another, smaller platform (1 by $2 \mathrm{~m}, 40 \mathrm{~cm}$ high) lies just beyond this continuous stretch of modified rubble and, directly beyond it, two $5 \mathrm{~m}$ long parallel alignments lie in the center of the tube floor. In some respects, they resemble alignments that delineate trails.

Evidence for human use occurs continuously for the next $425 \mathrm{ft}$ (600 ft from the entrance) but with less over all density. Included in this stretch are more leveled and rearranged break-down piles and several instances where single rock alignments, often in a retangular form, appear to delineate portions of the tube floor. The stones in some of these alignments had to have been brought to that specific locale because the ceiling and walls of the surrounding tube remained unbroken. Distinct scatters of bone (pig and bird), shell (mostly 'opihi), organic debris and charcoal concentrations occur along the tube floor in four sections. In many cases, the midden form small clusters adjacent to the tube walls, leaving the center of the floor free of refuse. Yent collected a basalt pestle and two adze from these midden areas. From 600 to $1264 \mathrm{ft}$ from entrance $\mathrm{U} 20$, the only indications of past use were very scattered pieces of shell, bone, charcoal, organic material and roof-fall that had obviously been shifted from its original location.

U21 (1090 ft el., Fig. 4b \& 5b) - About $25 \mathrm{ft}$ up-slope from the skylight the tube divides into a shallow, dead-ended upper passage and a lower passage through which the main tube continues. Below this divide, a false or greatly enhanced collapse pile blocks the main tube, allowing only a narrow passage along the $\mathrm{Ka}^{\prime} \mathrm{u}$ side of the pile and a small gap at the roofline which could be used for observation. Looking from the down-slope side, the blockade appears natural with the exception of a small $(1.5 \times 1.5 \mathrm{~m})$, slightly leveled area on the Hilo side of the rubble slope. The break-down pile below the skylight is uncharacteristically flat and uneven, suggesting that it was robbed of stone to build the blockade. The artificiality of the pile is obvious on the up-slope side and along the narrow passage where the rocks clearly form a stacked face. Charcoal and decayed sticks, with some 'opihi, are prevalent along the up-slope side of the tube floor for approximately $25 \mathrm{ft}$. 
the drip-line. Passage through the main tube was blocked, naturally, by a large collapse pile which can be skirted by crawling through a narrow space at the edge of the pile. About $50 \mathrm{ft}$ past the collapse, the tube narrows into a crawl way, and at the juncture of the collapse and the narrowed tube two bundle burials were placed in a small alcove.

U26 (1185 ft el., Fig. 4b, 4c) - Again, the outside entrance leads to an upper level of the tube while that to the main tube is a narrow segment blocked by breakdown-debris. To a great degree, this break-down appears to have been rearranged to conceal the passage. Access is only through an artificially created hole (50-60 $\mathrm{cm}$ wide) that is faced with flat roof fall slabs and leads to a drop of about $2 \mathrm{~m}$. A conveniently placed stone underneath the hole provides a foothold so that access is through lifting oneself in and out of the hole.

U26 (1185 ft el) to 27 (1435 ft el.) - A number of features are present in the long stretch between entrances 26 and 27 . Heading up-slope $1,972 \mathrm{ft}$, the first is an area of scattered charcoal concentrations and midden composed mostly of shell ('opihi) and some bone (including dog). Shortly beyond this area (205 ft), but clearly distinct from it, is a burial with three individuals. One is fully extended, lying on the floor perpendicular to the tube walls, while the bones of the other two are mixed with the lower half of the extended burial. A long, decaying stick lies along the length of the extended burial.

Approximately $3,890 \mathrm{ft}$ above these burials is another artificial barrier which blocks the main passage at a point where the lava tube divides into an upper and lower passage. While the upper level truncates after a short distance, the lower passage can be reached only by crawling through a small gap on the top of what appears to be a natural break-down pile if seen from the down-slope side. The upslope side of the pile, however, was not only clearly stacked but was also partially faced with upright stones. A mud-like mixture of charcoal and decayed organics was stuffed between the stones of the wall face, giving it the appearance of mortar. Instead of stabilizing the wall, this addition may have been an attempt to block the wind which can blow quite briskly through the lava tube. The modified breakdown covers the $5 \mathrm{~m}$ width of the lava tube and ranges in height from 1.5 to .75 m.

Further up-slope (125 ft), at least $130 \mathrm{ft}$ of the lava tube floor is littered with dense concentrations of charcoal, shell ('opihi) and bone midden and decayed organic material (including kukui nut). In one section ( 4.5 by $2 \mathrm{~m}$ ), long lines of decayed organic material, presumably the remnants of wooden sticks, form a lattice of four vertical strips and six horizontal ones. This lattice was partially lying against the lower edge of the tube wall, suggesting that it may have been a rack of some sort that was left partially propped against the tube wall. 
-

. $\mid$

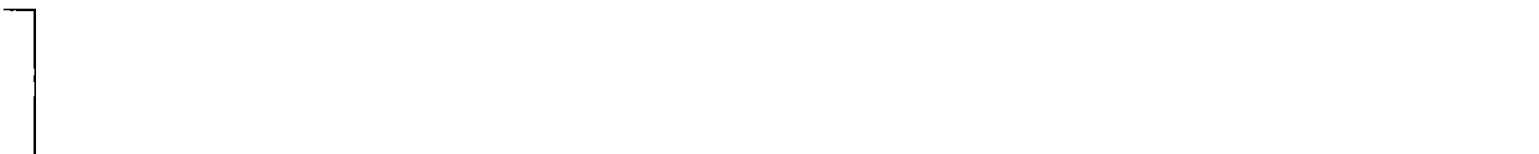
西 
Southern Tube, is fragmented. The large size of the tube openings indicate that it had been the main channel of a very-high volume flow but the flow probably did not run consistently or long enough to create a stable or continuous tube.

A total of 3 days was spent locating access routes to this tube system and finding the two segments which we mapped. Approximately eight to nine miles were covered in these efforts which included a brief reconnaissance of a forested kipuka to the southeast of the tube system. It was clear from the air that kukui trees (Aleurites moluccana) and ki plants (Cordyline terminalis), usually indicators of past Hawaiian use in an area, were prominent in portions of the kipuka. No structural features, such as agricultural mounds and walls or residential platforms, were seen in the kipuka but the abundance of kukui trees and ki plants do suggest that the area was probably cultivated, especially in the rocky depressions where soil accumulates.

Of the two tube segments visited, only the lower one $(50-10-55-14,899)$ contained evidence of human use, which included three burials and a structurally modified collapse pile (Fig. 6). Located at an elevation of $1,160 \mathrm{ft}$, we mapped this segment for a distance of $2,205 \mathrm{ft}$. The upper segment $(1,210 \mathrm{ft}$ el) was a relatively narrow and low tube ( 3 to $10 \mathrm{ft}$ high) which we could only map down-slope for $500 \mathrm{ft}$ (Fig. 7). No sign of past use was seen in any part of this upper segment.

The lower segment had to be entered by rope through a large, deep, overhung opening (Fig. 6:Entrance A). A single burial lies at the edge of the collapse pile about $10 \mathrm{~m}$ from this opening on the up-slope side. The bones were badly deteriorated and jumbled but, given the circular form of the scatter, it appears to have been a bundle burial. This was the only evidence of human use in the up-slope extent of the segment which could be followed only for $1500 \mathrm{ft}$ and had an average height of $8 \mathrm{ft}$ and width of $20 \mathrm{ft}$.

On the down-slope side, two more badly disturbed burials were found about $12 \mathrm{~m}$ from the entrance. One was placed directly behind a large slab of roof fall while another lies on top of a slab. Both were mixed with substantial amounts of charcoal or decayed organics and one contained two small blue beads indicating that these burial practices continued into the historic period.

A small skylight (Entrance B) lies $350 \mathrm{ft}$ down-slope from the first entrance and directly beneath it a platform was created from the break-down pile. The platform $(7 \mathrm{~m}$ by $4.5 \mathrm{~m})$ covers the width of the tube, but the varying degree to which the surface was filled and leveled with small rubble suggests that construction of the feature was not completed. On the platform and directly under the opening, a substantial pile of stones probably aided access through the opening, although a ladder or rope would still be needed to reach the skylight. The tube floor leading to the platform on the up-slope side was paved with flat, roof fall slabs forming a pathway about $5 \mathrm{~m}$ long. The location of these features beneath a 
.

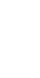


Fig. 7 Northern Lava Tube System - Upper and Lower Segments

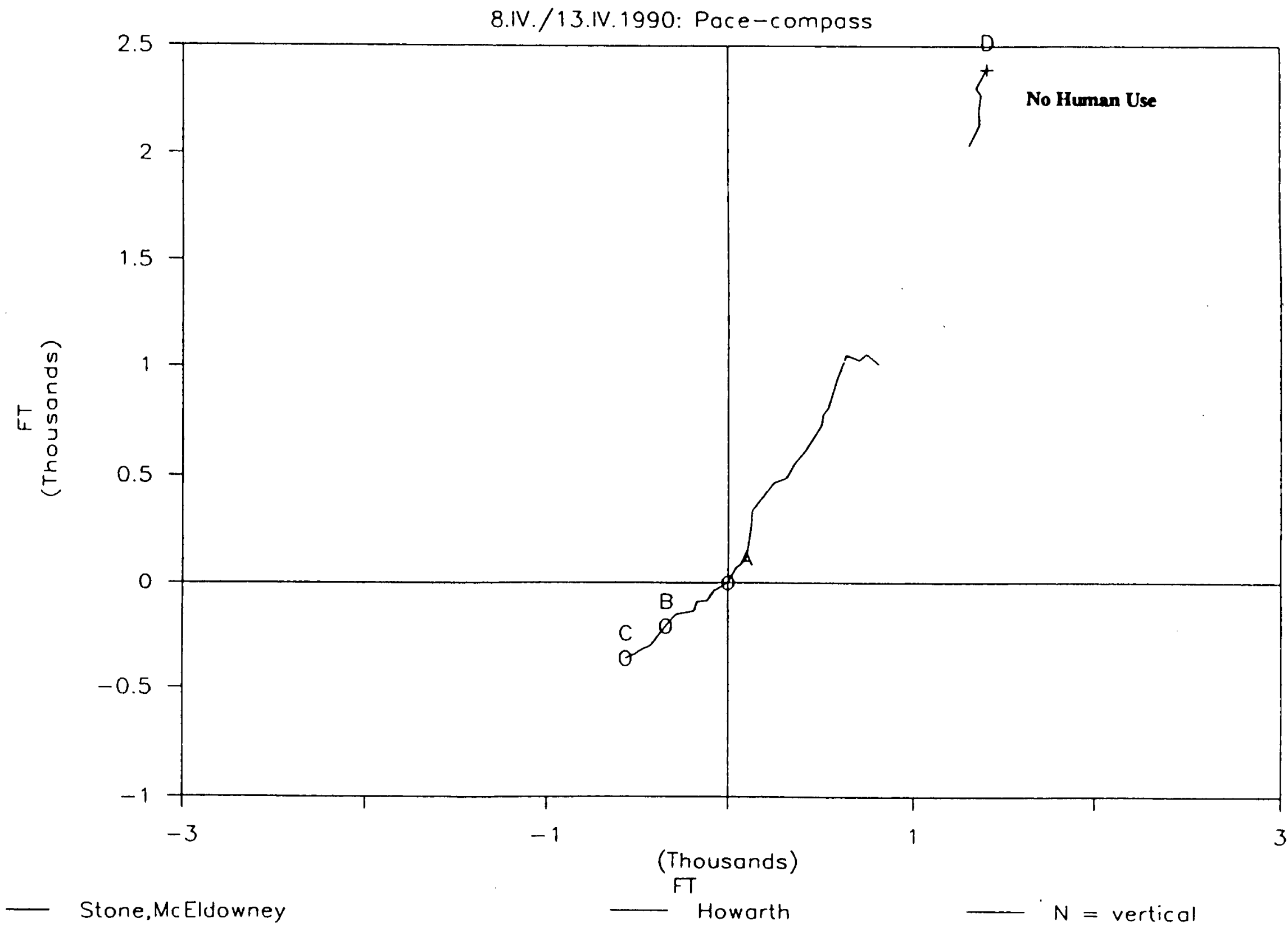




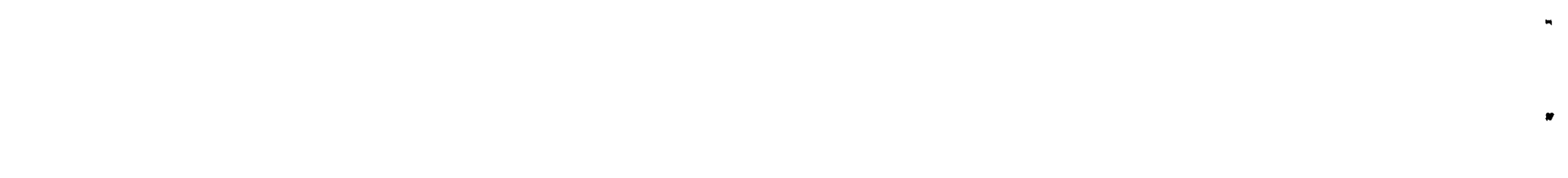
, 
Nicoletia meinerti (Lepismatiedae): silverfish

Cryptostigmata: mite

Mesostigmata: mite

Astigmata: mite

Oxidus gracilis (Diplopoda): alien millipede

The biological importance of preserving native invertebrate populations in the Middle Tube rests mainly with their uniqueness and diversity. Their uniqueness arises from the high degree of localized variation that occurs among taxa in the different tube systems of Puna. This has already been demonstrated for the native crickets and planthoppers collected in the Middle Tube. The State-funded, collaborative research effort being undertaken by researchers from the University of Hawaii and the Bishop Museum has shown that significant differences exist between the crickets of the Middle Tube and those of other tube systems. Similarly, the University of Marberg, Germany, study shows that the Middle Tube planthoppers vary significantly from others in the region, adding strength to the hypothesis that various populations have adapted to specific conditions in each lava tube. The diversity of the populations is shown in the cricket taxa where three closely related species of cave-adapted crickets in the genus Caconemebius co-exist in the Middle Tube. Only one other lava tube in Hawaii has this many native cricket species, and it is in a subdivision undergoing rapid deforestation.

It was suggested in the Supplemental EIS (1986:134) that disturbed wildlife may have to relocate to another area. If disturbance proves to be substantial and extensive it is unfounded to assume that native invertebrate fauna would migrate or that they could become established in neighboring areas where the forests may already be supporting a maximum number of native species. Given the great diversity of native species, neighboring forests or other lava tubes even a few miles away will have different species or varieties which may not be compatible with intruding migrators. More important, however, is the fact that the amount of forest to which species could migrate is diminishing. Substantial portions of neighboring forest land to south, west and north have been removed or depleted by the current eruption, expansion of papaya plantations, woodchipping and development within private subdivisions. Apart from the Kahaualea area, very little of the adjacent land currently has preservation zoning.

If the native invertebrates and the lava tube ecosystems in the Middle Tube are to be provided positive protection, the native forest above the course of the tube must be protected by an adequate buffer zone. These tube ecosystems are primarily dependent on tree roots, mostly those of Metrosideros sp. ('ohia), through which essential organic nutrients are continually renewed. 


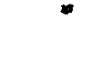
7 


\section{RECOMMENDATIONS AND CONSIDERATIONS}

Our recommendations for the treatment of known or potential lava tube segments within the Campbell Estate Land and the Geothermal Sub-Zone are covered by five major topics: significance evaluations for the historic properties identified during the survey: the justification and means for preserving the Middle Lava Tube System; procedures for predicting lava tubes and significant archaeological remains within the study area; identifying and protecting unknown lava tube segments which could contain historic remains (including burials); approaches that could minimize disturbance of undetected tubes during construction activities and drilling.

Most recommendations apply specifically to geothermal exploration and development within this Geothermal Sub-Zone and accommodate the guidelines stipulated in the CDUA Decision and Order (No. Ha-12/20/85) for these projects. In some cases, the suggested approaches could serve as guidelines for geothermal or other development projects in areas where lava tubes with historic remains are likely.

\section{Significance Evaluations:}

These initial significance assessments are based on criteria set out in the Draft Rules and Regulations of the State Historic Preservation Division which, with the exception of Criterion " $\mathrm{e}$ ", conform with those used to determine eligibility for inclusion in the National Register of Historic Places (36 CFR Part 60). All sites possess a high degree of integrity in location, setting, feeling and association.

1. Southern Tube Segment (Sites 14,901 - 3). These three tube segments were all used for burial and are therefore significant for their importance or value to the Hawaiian culture (Criterion " $\mathrm{e}$ "). They are also significant for the information they could yield (Criterion " $d^{\prime \prime}$ ).

2. Middle Lava Tube (Site 14,900). This extensive lava tube and the combined historic properties found over at least 9 miles of its length, is significant under several criteria. Despite probable looting of artifacts, most of the lava tube above the Pahoa Highway is essentially undisturbed. It contains burials and is therefore significant to the Hawaiian culture (Criterion " $e$ "). The numerous structural features and midden deposits found are significant for information they could yield on the prehistory of the region, particularly concerning past resource use and conflict (Criterion "d"). The walls built for defensive purposes embody the distinctive characteristics of a type and method of construction (Criterion " $c$ ") and exemplify a range of fortification structures. The possibly unfinished edifice at $\mathrm{U} 20$ is of particular important for demonstrating construction techniques. These 


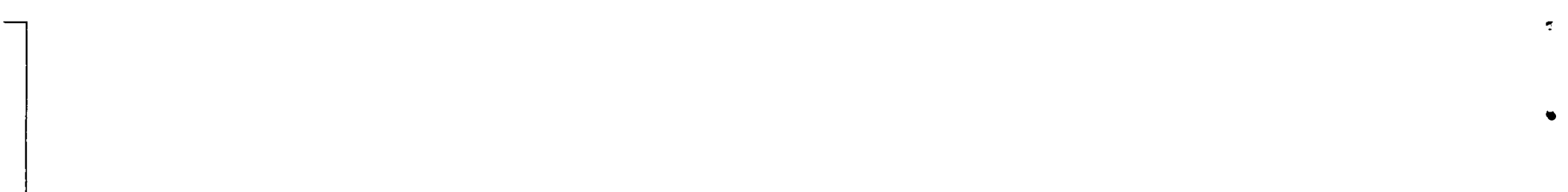

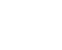


during the daytime and down the mountain at night. Within the lava tube, air nows generally up-tube during the day and down-tube at night. Our observations during the survey confirm that this pattern holds true for the Middle Lava Tube. If pollutants are accidentally released during exploration or development activities, surface air flow might be expected to disperse pollutants. In lava tubes, however, a heavier-than-air substance such as hydrogen sulfide could be confined or channeled for a long distance. Concentrations of these confined or channelled pollutants could impact invertebrate populations.

3. Definition of Buffer Zone Boundary. The boundary of the buffer zone should lie 1,500 ft to either side of a line which averages, in increments, the many bends and meanders in the tube's course. This places Alternative Well Site \#2 about 3,200 ft from the boundary and Alternative Well Site \# 3 about 3,500 ft from it. At the closest point, the Alternative Well Sites are 4,800 $\mathrm{ft}$ and 4,500 $\mathrm{ft}$ from the lava tube itself. If development plans followed that depicted in the Supplemental EIS (Fig. 5), development areas A and $\mathrm{C}$ would lie on the boundary of the buffer zone. An adequate buffer reduces the possibility of damage due to construction activities, accidental waste spillage or destruction of the forest above the tube. Final definition of this buffer zone should follow a more accurate survey of the portion of Middle Tube where it passes beneath Campbell Estate land.

4. Complete Mapping of the Middle Tube System. The Middle Lava Tube was only mapped to an elevation of $1,620 \mathrm{ft}$ and, based on its size at this point, we assume that it continues. We expect that continuous and diverse evidence of human use is unlikely in the upper, unmapped portions of the Middle Tube although burials could be present at entrances as is the case at entrance U29. If any exploration or development is planned for that portion of the sub-zone which lies above 1,620 ft and within the projected course of the buffer zone, then mapping of the Middle Tube should be continued.

5. Incorporation of Middle Tube in Historic Preserve. The Historic Preservation Division is considering setting aside the State-owned portion of the Middle Tube as an Historic Preserve. An agreement might be reached in which those portions of the Middle Tube which lie on Campbell Estate land are included in this Historic Preserve and managed accordingly. A management agreement is currently being negotiated by the State Department of Agriculture and University of Hawaii at Hilo for a portion of this lava tube that lies makai of the Pahoa Highway. Other lava tubes of comparable significance are held by multiple owners in private subdivisions and are therefore much more difficult to protect. 


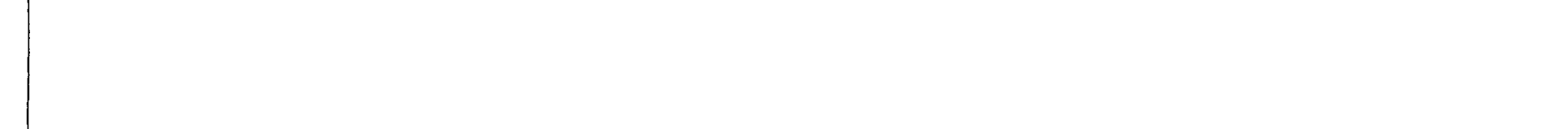

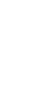

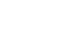


Some perceptions of the study area being remote probably arose when many of the basic themes and approaches used for the Kahaualea study were applied to the former Puna Forest Reserve. In the case of Kahaualea, the land division was a single ahupua' $a$ and more conventional land use patterns could be applied when predicting the probability of historic remains. Major settlement areas were depicted as being located near the coast while the agricultural or planting areas stretched up-slope until reaching the vast forested area which grew increasingly remote with elevation. This general orientation becomes more complex in the case of the Puna Forest Reserve. At least six ahupua'a converged in the study area from the south and the east (Holmes 1985) and generalized assessments of land use would have to be viewed as converging from these directions. A combination of factors, however, tended to focus attention on the southern approach to the Forest Reserve. The Geothermal Sub-Zone itself lies in the southern half of the property and both the studies by Holmes and Haun et al paid more attention to the southern slopes. For example, Holmes's map (1985:Fig. 22b) showing different types of land use only attempted to depict agricultural land and planting areas along the southern slope although they also occurred on older substrates to the southeast and east. Haun, Rosendahl and Landrum (1985) placed four of their five transects on the southern slope during their reconnaissance survey. With all agricultural areas identified to the south, it was probably assumed that, like Kahaualea, an increasingly remote forested area stretched inland from the depicted planting areas to the northern boundary of the Puna Forest Reserve. This skewed orientation probably contributed to the north flank lava tubes being overlooked in the literature reviews.

Also reducing the remoteness of the eastern side of the Forest Reserve is the presence of at least one substantial settlement in the interior. The accounts and maps produced by the U. S. Exploring Expedition in 1840 show a village named Kahuhali in the vicinity of what is now Pahoa. Such exceptions to the much more common coastal settlements generally occur where broad and gradual slopes allow an expanse of agriculturally suited environments to occur at substantial distances from the coast. The broad Lower Rift Zone and adjacent flanks are such an expanse and any inland settlements would increase the degree to which nearby areas were used.

The recent and active geologic history of the study area also has a bearing on how extensively the study ared was used for forest resources and cultivation, particularly when compared to other forested or agricultural lands at similar elevations. The mosaic of lava flow types and ages created both limitations and advantages. If much of the north flank of the East Rift is dominated by pahoehoe flows 300 to 500 years old or younger, then substantial portions of the study area were not forested when many of the predicted archaeological remains were created. Tall stature and diverse forests only develop after plant communities become established on new flows and then pass through varying stages of succession, a 

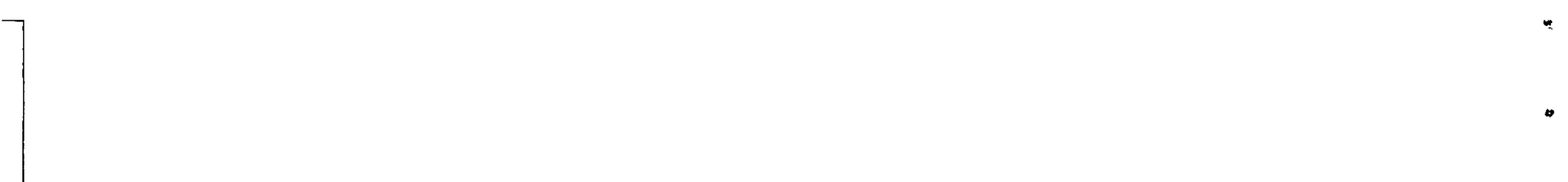
of trails shown by Wilkes as surrounding this hill was in Kahaualea. Holcomb (1987:317) thought that Wilkes' "Kalalua" was actually Heiheiahulu while we believe that it could be Iilewa, given the proportional distances and angles between this hill and other landmarks given on the map. A more thorough analysis of varying journal accounts and land records is needed to resolve this question, but with either interpretation, the main inland route taken by the Wilkes party still runs through the study area although farther to the south than shown by Holmes. Of the other trails shown as heading north or northeast from "Kalalua," only one would cross through the eastern side of the Forest Reserve. We concur with Holmes that the inland route running parallel to the Rift was a well-known and established route although, as noted by Pickering (1840-41:182), his guides during the Expedition preferred to go down to Kalapana and up through Panau to reach the Volcano rather than to take the more arduous inland trail with few places to get provisions.

\section{Identification and Protection of Lava Tube Segments}

\section{Recommended Survey Procedures for Identifying Lava Tubes Near}

Construction Area. To improve the probability of finding lava tubes that could run beneath a well site, we recommend that a systematic survey be made of a rectangular area measuring 1,000 ft up-slope and down-slope of each proposed well site (area to be disturbed around the drilling rig) and $500 \mathrm{ft}$ to the northwest and southeast. The survey would, if the current well sites are representative in size, be about $2,400 \mathrm{ft}$ long and $1,400 \mathrm{ft}$ wide. The survey corridor should be aligned due northeast to southwest which offsets it slightly from the general trend of Kilauea's East Rift Zone. This roughly reflects the trend of the major tube systems and flows on Kilauea's north flank. For projects elsewhere, the corridor alignment would have to reflect the dominant flow direction of that particular area. Although two segments of the Middle Tube System run for 1.4 and 1.5 miles without openings, we feel a $2,000 \mathrm{ft}$ long survey corridor would have located many entrances from different points along the tube's course. The 1,000 ft width of the corridor accommodates the degree to which the tube meanders between most entrances.

2. Coverage within the Survey Corridor. To locate entrances within the survey corridor we feel that visual coverage should be as close to $100 \%$ as possible unless a sampling design can be devised which targets particular flow types or formations that prove, over time, to be associated with a high incidence of lava tubes. The analysis of clear, low level aerial photographs and maps of the vegetation, geology and surface topography could help identify indicators of tube openings or trends. A sampling design would help lessen problems of reduced mobility and low ground visibility due to dense vegetation and hazardous ground conditions. 
mitigation measures to take place immediately. Such follow-up measures could include use of a down-hole camera to help determine if the void is a lava tube and if historic remains were likely. If they are, then additional surveys would be needed to find an entrance to the tube, to assess any historic remains present and to propose an appropriate mitigation plan. Alternatively, the specific well site could be moved to avoid the cavity.

\section{BIBLIOGRAPHY}

Baldwin, E.D. 1902 Map Showing a Portion of Puna District, Hawaii. Hawaii Territory Survey. Survey Office, Department of Accounting and General Services, State of Hawaii.

Bonk, William J. 1988 An Archaeological Reconnaissance Survey in the Geothermal Resource Subzone of Upper Kaimu and Makena, Puna, Hawaii. Report prepared for Mid-Pacific Geothermal.

---. 1989a An Archaeological Monitoring and Additional Reconnaissance Survey in the Geothermal Resource Subzone of Upper Kaimu, Makuu, Kaohe, Kehena,Kaapahu and Kamaili, Puna, Hawaii. Report prepared for Mid-Pacific Pacific Geothermal.

.--. 1989b An Archaeological Reconnaissance Survey in the Geothermal Resource Subzone of Upper Kaimu, Makuu, Kaohe, Kehena, Kaapahu and Kamaili, Puna, Hawaii. Report prepared for Mid-Pacific Geothermal.

---. 1989c Additional Notes on an Archaeological Survey in the Geothermal Resource Subzone of Upper Kamaili, Kehena and Kikala, Puna, Hawaii. Letter Report prepared for Hawaii Natural Energy Institute, University of Hawaii.

-.-. 1990 An Archaeological Reconnaissance Survey in the Geothermal Resource Subzone of Upper Kaimu, Makuu, Kaohe, Kehena, Kaapahu and Kamaili, Puna, Hawaii. Report prepared for True Mid-Pacific Geothermal, Inc.

Cordy, Ross. 1989 Research Design for Archaeological Survey Methods. Archaeological Plan for Geothermal Exploration Activities, True/Mid-Pacific Geothermal Venture (Required under CDUA HA-1830)

Cultural Surveys of Hawaii. 1989 Part VI: Cultural Resources". In Draft Environmental Review: $500 \mathrm{MW}$ Geothermal Development within Puna District, Island of Hawaii. Prepared by MCM Planners. 
Howarth, F.G. and Stone, F.D. 1982 The conservation of Hawaii's cave resources, pp. 94-99. In: Proc. 4th Conference in Natural Science, Hawaii Volcanoes National Park. Coop. Nat. Park Res. Study Unit, Dept. Botany, U.H. Manoa, Honolulu, HI

Howarth, F.G., Hoch, H. and Asche, M. 1990 Duets in darkness: species-specific substrate-borne vibrations produced by cave-adapted cixiid planthoppers in Hawaii (Homoptera: Fulgoroidea). Memoires de Biospeologie.

Kennedy, Joseph 1989 Research Design for Future Exploration of Geothermal Development in the Wao Kele O Puna Natural Area Reserve. Letter Report to Rod Moss, Mid-Pacific Geothermal, May 28.

-..-. 1990 Archaeological Inventory Survey of Proposed Well Site \#2, Wao Kele O Puna Natural Area Reserve, Puna, Island of Hawaii. Letter Report to Alan Kawada, Sept. 6.

Lamoureux, C.H. 1990 Botanical Survey of Proposed New Well Site \#2. Report prepared for True Geothermal Energy Company and Mid-Pacific, Inc.

Lamoureux, C.H., W.A. Wistler and C.T. Imada. 1990 Botanical Survey of Proposed Well Sites 2 and 3 and of the Proposed Roads Leading to these Sites from Well Site 1. Report prepared for True Geothermal Energy Company and Mid-Pacific Geothermal, Inc.

Pickering, C. 1840-41 Journal Kept While on the U.S. Exploring Expedition, 18381840." Ms. in the Academy of Natural Sciences, Philadelphia, Pa.

Stone, F.D. 1988 Adaptive radiation among surface and cave dwelling nemobiine crickets on the island of Hawaii. XVIII International Congress of Entomology, Vancouver, B.C. Canada, July 3-9, 1988

Stone, F.D. and D. Tanaka. 1988 National Speleological Society Convention, Hot Springs, South Dakota, July, 1988 Abstract.

True/Mid-Pacific Geothermal Venture with The Estate of James Campbell. 1989 Final Supplemental Environmental Impact Statement to the Revised Environmental Impact Statement for the Kahaualea Project.

Yent, Martha 1983 Survey of a Lava Tube, Pahoa, Puna, Hawaii Island, TMK: 1-5-08: 1. Report Prepared for the Department of Land and Natural Resources, Division of State Parks (Historic Sites) and Forestry. 